\title{
Evaluation of Microbial Colonization on Orthodontic Attachments: A Prospective Study
}

\author{
Shruthi DP ${ }^{1^{*}}$, Nagaraj B Malipatil ${ }^{2}$ and Prithviraj DR ${ }^{3}$ \\ ${ }^{1}$ Department of Orthodontics and Dentofacial Orthopedics, Dayanand Sagar College of Dental Sciences, Bangalore, India \\ ${ }^{2}$ Private Practitioner, No 206, Nithyashree Sankalp Apartments, Subramanyapura Main Road, Chikalasandra, Bangalore, India \\ ${ }^{3}$ Department of Prosthodontics, Govt. Dental College, Bangalore, India
}

*Corresponding author: Shruthi DP, Former Post Graduate, Department of Orthodontics and Dentofacial Orthopedics, Dayanand Sagar College of Dental Sciences, Bangalore, India, Tel: 9900705819; E-mail: shruthiprithvi@gmail.com

Rec date: Dec 10, 2014, Acc date: Dec 27, 2014, Pub date: Dec 29, 2014

Copyright: (C) 2014 Shruthi DP, et al. This is an open-access article distributed under the terms of the Creative Commons Attribution License, which permits unrestricted use, distribution, and reproduction in any medium, provided the original author and source are credited.

\begin{abstract}
Orthodontic attachments interfere with oral hygiene maintenance leading to plaque accumulation and ultimately enamel demineralization caused by oral microflora. Orthodontists must have a clear understanding of the nature and the type of microflora present to combat with the above stated problem. This study was done to isolate and identify the microflora from orthodontic attachments and to study the quality of oral microflora during fixed mechanotherapy at regular intervals. In this prospective clinical study, ten patients were selected for arch wire ligation with commonly used elastic modules. One elastic module was removed from each patient at regular intervals of $24 \mathrm{hrs}, 7,14$ and 21 days for isolation and qualitative assessment of the microbial growth. Aerobic inoculation was done using nichrome inoculating wire. Further subspeciation was done using certain biochemical reactions like fermentation of sugar. For anaerobic growths Mac-Intosh jar was used. The study revealed that there was minimal or no growth of aerobes and anerobes after 24 hours. However, with increased duration of time there was progressive colonization of microbes (both commensals and pathogenic) on the orthodontic attachments. On examination of orthodontic attachments over a scheduled period of time anaerobic microorganisms were isolated which indicates that patients undergoing fixed mechanotherapy should exercise maximum oral hygiene with oral hygiene adjunctive aids other than routine brushing and should also undergo periodic oral prophylaxis so as to avoid any iatrogenic damage and alteration of the oral environment.
\end{abstract}

Keywords: Orthodontic appliance; Oral hygiene; Oral microbiology

\section{Introduction}

There are more than 600 bacterial species comprise plaque microflora that exists on surface within the oral cavity. Frequent changes in environmental condition within the oral cavity can lead to changes in the composition of the microflora. There is increase prevalence of oral ailments such as dental caries, gingivitis and periodontitis when orthodontic appliances attached to the enamel surface of teeth [1]. With growing awareness of esthetics in general population there is a huge demand for active orthodontic treatment which usually spans to a year or little more. Fixed orthodontic appliances are considered very efficient in bringing about active orthodontic treatment [2]. The fixed orthodontic appliances makes tooth cleaning more difficult and favors plaque formation on the tooth surface. These appliances also restrict the self-cleansing action of the tongue, lips and cheek to remove food debris from the tooth surface. Therefore, accumulated food debris, predominantly fermentable carbohydrates, encourages growth of the cariogenic bacteria such as Streptococcus mutans and Lactobacillus. Most growth sites are usually found on the gingival margin and on the edges of orthodontic bands [3]. The drawback of these fixed attachments are accumulation and retention of plaque which constitutes a high risk of white spot lesion and enamel demineralization if the patient does not maintain the oral hygiene or use appropriate oral hygiene aids [4]. Though, mechanical aids for oral hygiene are recommended to the patients, adequate mouthwashes also need to be prescribed for which the orthodontists should have a clear knowledge of the kind of microflora present and to combat the same [5]. The presence of foreign body (in this study, fixed appliances) can lead to increased accumulation of pathogenic bacteria and increased risk of caries and infections if proper oral hygiene is not maintained. The aim of this study was to isolate and identify the quality of microbes present in the oral cavity during fixed mechanotherapy.

\section{Materials and Methods}

\section{Inclusion criteria}

All patients were in good health, none had taken antibiotic for 3 months before the baseline examination and during treatment, and no clinical signs of gingival inflammation were present at baseline. All patients were in permanent dentition, free of dental plaque and motivated for good oral hygiene.

\section{Exclusion criteria}

Excluded patients were smokers, pregnant and lactating women, patients on systemic medications for chronic diseases, those who had undergone periodontal treatment within 3 months before the baseline examination, and those with systemic disorder that could influence microbiologic condition of the oral cavity.

Ten patients (age $18 \pm 2$ years, 7 males and 3 females) undergoing fixed orthodontic treatment in Department of Orthodontics and 
Page 2 of 4

Dentofacial Orthopaedics, Dayananda Sagar College of Dental Sciences and Hospital were selected randomly for this study. Informed consent has been obtained from the participating patients for the study.

\section{Methodology}

In all patients arch wires were ligated with commonly used elastic modules and the patients were followed regularly over a period of 21 days. Samples were collected periodically at $24 \mathrm{hrs}$, on day 7, on day 14 and on day 21. At the end of 24 hours, one elastic module was removed from each patient and stored in sterile air-tight containers and sent to laboratory for isolation and qualitative assessment of the microbial growth on the elastic module. The same procedure was repeated at regular intervals on day 7, 14 and 21 .

Commonly used culture media for isolation of microbes are MacKonkey's agar, Robertson's cooked meat medium, Blood agar, Chocolate agar. Aerobic inoculation was done using nichrome inoculating wire. Further sub-speciation was done using certain biochemical reaction like fermentation of sugar. For anaerobic growths Mac-Intosh jar was used.

\section{Results}

The study revealed that there was minimal or no growth of aerobes and anaerobes at 24 hours. However with increased duration of time there was progressive colonization of microbes (both commensals and pathogenic) on the orthodontic attachment (Figures 1 and 2).

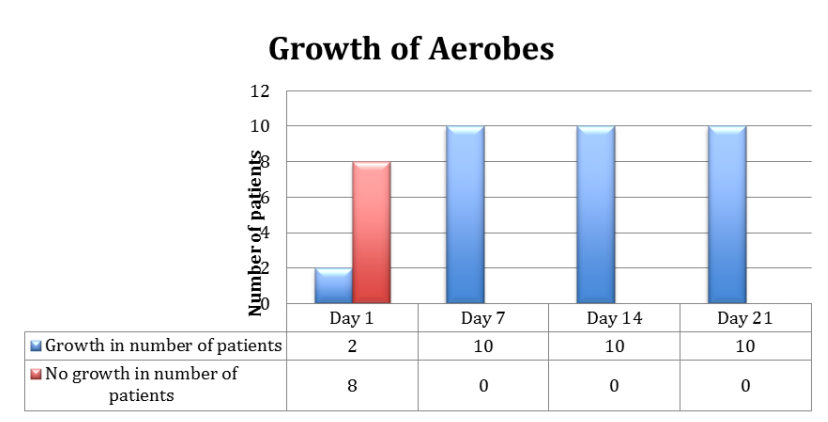

Figure 1: Growth of Aerobes.

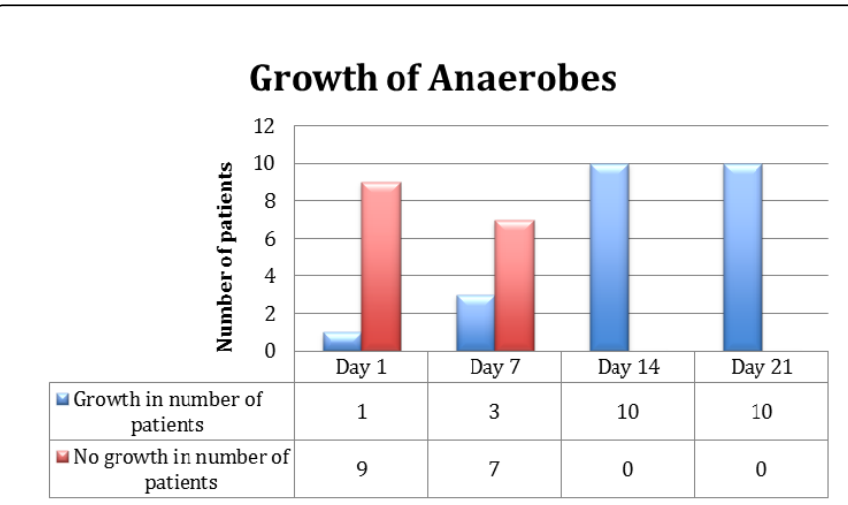

Figure 2: Growth of Anaerobes.

\section{Discussion}

Oral hygiene is significant prophylactic program in receiving good orthodontic treatment. Fixed orthodontic appliances impede good oral hygiene and leads to plaque retention and harboring pathogenic microflora. Decrease in $\mathrm{pH}$, increased affinity of bacteria to the metallic surface because of electrostatic reactions are the main factor occurred due to fixed orthodontic appliance component causing alteration in oral microflora [6,7]. Proportion of microflora in this study demonstrated the increase in trend of pathogenic flora with increase in time duration as evident from the Table 1. Similar observations were made by Venkatraman $\mathrm{C}$ et al. and Huser $\mathrm{MC}$ et al. in their prospective studies $[7,8]$.

Some studies have shown that the elastomeric ring exhibit bacterial plaque on its surface, with a higher number of microorganisms than can be verified on tooth surfaces because of its rough surface and the absorption properties of this material [9-11]. The design and surface characteristic of both orthodontic attachment and composite may influence plaque retention. The method of ligation of the arch wire is an additional factor of importance [10].

In the present study there was no colonization of microorganisms after 24 hours except in two patients where Staphylococcus was found. Subsequently the culture examination at the end of 7 th day showed growth of aerobic commensals like Strep. oralis, Strep. sanguinis in all the patients. Other commensal like Strep. parasanguinis and Strep. mitis were also noticed in few samples. There was no growth of anaerobes except in three specimens where $L$. acidophilus, $L$. casei and Peptostreptococcus were found. Total $80 \%$ of patients did not show growth of aerobic microoraginsm while in $90 \%$ patients there was absence of anaerobic microbial growth after $24 \mathrm{hrs}$. Sukontapatipark et al. reported that in first week prevalence of cocci is more after fixed orthodontic appliances [10].

At the end of 14th day both aerobes and anaerobes increased with the appearance of Strep. mutans (caries causing microorganism) in half the number of specimens.

At the end of 21st day, the presence of Strep. mutans was noticed in all the specimens along with the other commensals. The enamel demineralization is caused by organic acids, produced mainly by mutans streptococci. Strep. mutans is one of the main causative organisms of human dental caries [12]. The increase in bacteria Streptococci is generally related to higher incidence of caries [3]. Similar results observed in previous studies, forseberg et al., Türkkahraman et al., also demonstrated a significant increase in the number of S. mutans and lactobacilli in dental plaque [13]. The results obtained in this study are also consistent with results reported by Alves desouza et al., Anhori et al. and Ahn et al. [12-15].

With the increase in time there is colonization of microbes around the orthodontic attachments. This may be attributed to orthodontic attachments acting as retention for dental plaque. The plaque may act as a contributing factor for development of dental caries or periodontal diseases. Maintaining strict control of oral hygiene is required for orthodontic patients after appliance placement that will minimize the possibility of tooth decalcification and development of inflammatory periodontal disease [3].

Small sample size and lack of quantitative analysis of pathogenic bacteria in this study necessitates further studies involving large patient population with quantitative assessment of pathogenic bacteria. 
Citation: Shruthi DP, Malipatil NB, Prithviraj DR (2014) Evaluation of Microbial Colonization on Orthodontic Attachments: A Prospective Study. J

Page 3 of 4

\begin{tabular}{|c|c|c|c|c|c|c|c|c|}
\hline \multirow[b]{2}{*}{ Sr. No } & \multicolumn{2}{|l|}{ Day 1} & \multicolumn{2}{|l|}{ Day 7} & \multicolumn{2}{|l|}{ Day 14} & \multicolumn{2}{|l|}{ Day 21} \\
\hline & Aerobes & Anaerobes & Aerobes & Anaerobes & Aerobes & Anaerobes & Aerobes & Anaerobes \\
\hline 1 & No growth & No growth & $\begin{array}{l}\text { Staphylococcus } \\
\text { Strep. oralis } \\
\text { Strep. sanguinis }\end{array}$ & No growth & $\begin{array}{l}\text { Staphylococcus } \\
\text { Strep. oralis } \\
\text { Strep. sanguinis } \\
\text { Strep. mutans }\end{array}$ & $\begin{array}{l}\text { Peptostreptococci, } \\
\text { Propionobacterium }\end{array}$ & $\begin{array}{l}\text { Staphylococcus, } \\
\text { Strep. } \\
\text { Sanguinis, } \\
\text { Strep. mutans }\end{array}$ & $\begin{array}{l}\text { Peptostreptococci, } \\
\text { Propionobacterium }\end{array}$ \\
\hline 2 & $\begin{array}{l}\text { Staphylococc } \\
\text { us }\end{array}$ & No growth & $\begin{array}{l}\text { Staphylococcus } \\
\text { Strep. oralis } \\
\text { Strep. sanguinis } \\
\text { Strep. } \\
\text { parasanguinis }\end{array}$ & $\begin{array}{l}\text { L. acidophilus } \\
\text { L. casei }\end{array}$ & $\begin{array}{l}\text { Staphylococcus } \\
\text { Strep. oralis } \\
\text { Strep. sanguinis } \\
\text { Strep. mitis }\end{array}$ & $\begin{array}{l}\text { Propionobacterium } \\
\text {, Bifidobacterium } \\
\text { L. casei }\end{array}$ & $\begin{array}{l}\text { Staphylococcus, } \\
\text { Strep. } \\
\text { Sanguinis, } \\
\text { Strep. mutans }\end{array}$ & $\begin{array}{l}\text { Propionobacterium } \\
\text {, Bifidobacterium } \\
\text { L. casei }\end{array}$ \\
\hline 3 & No growth & No growth & $\begin{array}{l}\text { Staphylococcus } \\
\text { Strep. oralis } \\
\text { Strep. sanguinis } \\
\text { Strep. mitis }\end{array}$ & $\begin{array}{l}\text { Peptostreptococci } \\
\text { L. casei }\end{array}$ & $\begin{array}{l}\text { Staphylococcus } \\
\text { Strep. oralis } \\
\text { Strep. sanguinis } \\
\text { Strep. } \\
\text { parasanguinis }\end{array}$ & $\begin{array}{l}\text { Peptostreptococci } \\
\text { L. acidophilus } \\
\text { L. casei }\end{array}$ & $\begin{array}{l}\text { Staphylococcus, } \\
\text { Strep. } \\
\text { Sanguinis, } \\
\text { Strep. } \\
\text { parasanguinis } \\
\text { Strep. mutans }\end{array}$ & $\begin{array}{l}\text { Peptostreptococci } \\
\text { L. acidophilus } \\
\text { L. casei }\end{array}$ \\
\hline 4 & No growth & L. acidophilus & $\begin{array}{l}\text { Staphylococcus } \\
\text { Strep. oralis } \\
\text { Strep. sanguinis }\end{array}$ & No growth & $\begin{array}{l}\text { Staphylococcus } \\
\text { Strep. oralis } \\
\text { Strep. mutans } \\
\text { Strep. mitis }\end{array}$ & $\begin{array}{l}\text { Peptostreptococci, } \\
\text { Bifidobacterium }\end{array}$ & $\begin{array}{l}\text { Staphylococcus, } \\
\text { Strep. } \\
\text { Sanguinis, } \\
\text { Strep.oralis } \\
\text { Strep. mutans }\end{array}$ & $\begin{array}{l}\text { Peptostreptococci, } \\
\text { Bifidobacterium }\end{array}$ \\
\hline 5 & No growth & No growth & $\begin{array}{l}\text { Staphylococcus } \\
\text { Strep. oralis } \\
\text { Strep. sanguinis } \\
\text { Strep. } \\
\text { parasanguinis }\end{array}$ & No growth & $\begin{array}{l}\text { Staphylococcus } \\
\text { Strep. oralis } \\
\text { Strep. sanguinis } \\
\text { Strep. } \\
\text { parasanguinis }\end{array}$ & $\begin{array}{l}\text { Peptostreptococci, } \\
\text { Bifidobacterium } \\
\text { Actinomyces } \\
\text { odontolyticus }\end{array}$ & $\begin{array}{l}\text { Staphylococcus, } \\
\text { Strep. } \\
\text { Sanguinis, } \\
\text { Strep. mutans }\end{array}$ & $\begin{array}{l}\text { Peptostreptococci, } \\
\text { Bifidobacterium } \\
\text { Actinomyces.odon } \\
\text { tolyticus }\end{array}$ \\
\hline 6 & No growth & No growth & $\begin{array}{l}\text { Staphylococcus } \\
\text { Strep. oralis } \\
\text { Strep. sanguinis } \\
\text { Strep. mitis }\end{array}$ & No growth & $\begin{array}{l}\text { Staphylococcus } \\
\text { Strep. oralis } \\
\text { Strep. sanguinis } \\
\text { Strep. mitis } \\
\text { Strep. mutans }\end{array}$ & $\begin{array}{l}\text { Peptostreptococci } \\
\text { L. acidophilus } \\
\text { L. casei }\end{array}$ & $\begin{array}{l}\text { Staphylococcus, } \\
\text { Strep.mitis, } \\
\text { Strep.oralis } \\
\text { Strep. mutans }\end{array}$ & $\begin{array}{l}\text { Peptostreptococci } \\
\text { L. acidophilus } \\
\text { L. casei }\end{array}$ \\
\hline 7 & $\begin{array}{l}\text { Staphylococc } \\
\text { us }\end{array}$ & No growth & $\begin{array}{l}\text { Staphylococcus } \\
\text { Strep. oralis } \\
\text { Strep. sanguinis } \\
\text { Strep. mitis }\end{array}$ & $\begin{array}{l}\text { Peptostreptococci } \\
\text { L. acidophilus }\end{array}$ & $\begin{array}{l}\text { Staphylococcus } \\
\text { Strep. oralis } \\
\text { Strep. sanguinis } \\
\text { Strep. } \\
\text { parasanguinis } \\
\text { Strep. mutans }\end{array}$ & $\begin{array}{l}\text { Peptostreptococci } \\
\text { L. acidophilus } \\
\text { L. casei }\end{array}$ & $\begin{array}{l}\text { Staphylococcus, } \\
\text { Strep. } \\
\text { parasanguinis, } \\
\text { Strep. mutans }\end{array}$ & $\begin{array}{l}\text { Peptostreptococci } \\
\text { L. acidophilus } \\
\text { L. casei }\end{array}$ \\
\hline 8 & No growth & No growth & $\begin{array}{l}\text { Staphylococcus } \\
\text { Strep. oralis } \\
\text { Strep. sanguinis } \\
\text { Strep. } \\
\text { parasanguinis }\end{array}$ & No growth & $\begin{array}{l}\text { Staphylococcus } \\
\text { Strep. oralis } \\
\text { Strep. sanguinis } \\
\text { Strep. mitis }\end{array}$ & Peptostreptococci & $\begin{array}{l}\text { Staphylococcus, } \\
\text { Strep. } \\
\text { Sanguinis, } \\
\text { Strep. mutans }\end{array}$ & Peptostreptococci \\
\hline 9 & No growth & No growth & $\begin{array}{l}\text { Staphylococcus } \\
\text { Strep.Oralis } \\
\text { Strep.Sanguinis }\end{array}$ & No growth & $\begin{array}{l}\text { Staphylococcus } \\
\text { Strep. oralis } \\
\text { Strep. sanguinis } \\
\text { Strep. } \\
\text { parasanguinis }\end{array}$ & $\begin{array}{l}\text { Peptostreptococci, } \\
\text { Propionobacterium }\end{array}$ & $\begin{array}{l}\text { Staphylococcus, } \\
\text { Strep. } \\
\text { Sanguinis, } \\
\text { Strep.oralis } \\
\text { Strep. mutans }\end{array}$ & $\begin{array}{l}\text { Peptostreptococci, } \\
\text { Propionobacterium }\end{array}$ \\
\hline 10 & No growth & No growth & $\begin{array}{l}\text { Staphylococcus } \\
\text { Strep. oralis }\end{array}$ & No growth & $\begin{array}{l}\text { Staphylococcus } \\
\text { Strep. oralis }\end{array}$ & $\begin{array}{l}\text { Peptostreptococci, } \\
\text { Bifidobacterium }\end{array}$ & $\begin{array}{l}\text { Staphylococcus, } \\
\text { Strep. mitis }\end{array}$ & $\begin{array}{l}\text { Peptostreptococci, } \\
\text { Bifidobacterium }\end{array}$ \\
\hline
\end{tabular}


Citation: Shruthi DP, Malipatil NB, Prithviraj DR (2014) Evaluation of Microbial Colonization on Orthodontic Attachments: A Prospective Study. J

\begin{tabular}{|l|l|l|l|l|l|l|l|}
\hline & & $\begin{array}{l}\text { Strep. sanguinis } \\
\text { Strep. } \\
\text { parasanguinis }\end{array}$ & & $\begin{array}{l}\text { Strep. sanguinis } \\
\text { Strep. mitis } \\
\text { Strep. mutans }\end{array}$ & & Strep. mutans \\
\end{tabular}

Table 1: List of isolated microorganisms.

\section{Conclusion}

The use of elastomeric modules promotes significant retention of biofilm and plaque, leading to colonization of pathogenic microflora. Patients should be educated and motivated to maintain good oral hygiene. At the same time treatment should be individualized and optimized in order to minimize iatrogenic damages.

\section{References}

1. Komori R, Sato T, Takano-Yamamotoa T, Takahashi N (2012) Microbial composition of dental plaque microflora on first molars with orthodontic bands and brackets, and the acidogenic potential of these bacteria. J Oral Biosci 54: 107-112.

2. Lauritano D, Caccianiga G (2013) Periodontal aspects in orthodontics. OA Dentistry 01: 1-7.

3. Freitas AO, Marquezan M, Nojima Mda C, Alviano DS, Maia LC (2014) The influence of orthodontic fixed appliances on the oral microbiota: a systematic review. Dental Press J Orthod 19: 46-55.

4. Srivastava K, Tikku T, Khanna R, Sachan K (2013) Risk factors and management of white spot lesions in orthodontics. J Orthod Sci 2: 43-49.

5. Dannan A (2008) Evaluation of Oral Hygiene Instructions' Awareness during Orthodontic Treatment among Syrian Orthodontists. The Internet J Dental Science 8: 1.

6. Mishra V, Ahuja NK, Gupta N, Raghav P (2012) Effect Of Two Different Materials Used For Arch Wire Ligation On Microbial Colonization Indian Journal of Dental Sciences 4: 38.

7. Venkatraman C, Bhatnagar D (2007) Study of proportion of Microflora in Orthodontic Clinic. J Ind Orthod Soc; 41: 142-146.
8. Huser MC, Baehni PC, Lang R (1990) Effects of orthodontic bands on microbiologic and clinical parameters. Am J Orthod Dentofacial Orthop 97: 213-218.

9. Rembowski Casaccia G, Gomes JC, Alviano DS, de Oliveira Ruellas AC, Sant' Anna EF (2007) Microbiological evaluation of elastomeric chains. Angle Orthod 77: 890-893.

10. Sukontapatipark W, el-Agroudi MA, Selliseth NJ, Thunold K, Selvig KA (2001) Bacterial colonization associated with fixed orthodontic appliances. A scanning electron microscopy study. Eur J Orthod 23: 475-484.

11. Forsberg CM, Brattström V, Malmberg E, Nord CE (1991) Ligature wires and elastomeric rings: two methods of ligation, and their association with microbial colonization of Streptococcus mutans and lactobacilli. Eur J Orthod 13: 416-420.

12. Ahn SJ, Lim BS, Yang HC, Chang YI (2005) Quantitative analysis of the adhesion of cariogenic streptococci to orthodontic metal brackets. Angle Orthod 75: 666-671.

13. Türkkahraman H, Sayin MO, Bozkurt FY, Yetkin Z, Kaya S, et al. (2005) Archwire ligation techniques, microbial colonization, and periodontal status in orthodontically treated patients. Angle Orthod 75: 231-236.

14. Alves de Souza R, Borges de Araújo Magnani MB, Nouer DF, Oliveira da Silva C, Klein MI, Sallum EA, Gonçalves RB (2008) Periodontal and Microbiologic evaluation of 2 methods of archwire ligation: ligature wires and Elastomeric rings. American Journal of Orthodontics and Dentofacial Orthopedics; 34: 506-512.

15. Anhoury P, Nathanson D, Hughes CV, Socransky S, Feres M, et al. (2002) Microbial profile on metallic and ceramic bracket materials. Angle Orthod 72: 338-343. 